\title{
The cestode Atractolytocestus huronensis (Caryophyllidea) continues to spread in Europe: new data on the helminth parasite of the common carp
}

\author{
M. Oros ${ }^{1}$, V. Hanzelová ${ }^{1, *}$, T. Scholz ${ }^{2}$ \\ ${ }^{1}$ Parasitological Institute, Slovak Academy of Sciences, Hlinkova 3, 04001 Košice, Slovakia \\ ${ }^{2}$ Institute of Parasitology, Academy of Sciences of the Czech Republic, Branišovská 31, 37005 České Budějovice, \\ Czech Republic
}

\begin{abstract}
The caryophyllidean tapeworm Atractolytocestus huronensis Anthony, 1958, originally described from the common carp Cyprinus carpio carpio L. from North America, has recently been introduced into Europe (UK, Hungary). In the present study, the dispersion of the tapeworm in other countries of Central Europe (Slovakia and the Czech Republic) is described, including its first observation in the common carp of the Tisa River, southeastern Slovakia. Because of the transboundary location of the river, there are possible consequences of the rapid distribution of the parasite to other regions throughout the Danube River basin. The parasite has also been found in cultured carp from fishponds in South Bohemia, from where the carp are imported to many European countries. Rapid dissemination of this cestode in Europe indicates its ability to colonise new regions, and represents another example of man-made introduction of potential pathogens of carp and other farmed fish. The morphology of the A. huronensis specimens found is compared with that of specimens from Hungary and North America as well as that of Atractolytocestus sagittatus (Kulakovskaya and Akhmerov, 1965) from the same fish host in eastern Asia.
\end{abstract}

KEY WORDS: Atractolytocestus huronensis · Common carp · Cyprinus carpio carpio · Man-made introduction · Europe

\section{INTRODUCTION}

The helminth fauna of the common carp Cyprinus carpio carpio L. in Europe has been studied intensively due to its importance for aquaculture and fishery (Bauer et al. 1973, Baruš et al. 2002). However, it has changed considerably during the last decades due to man-made introductions of new parasites, mostly those originally occurring in East Asia (Bauer et al. 1973, Kennedy 1994). Among these parasites, the cestodes Bothriocephalus acheilognathi Yamaguti, 1934 (Pseudophyllidea: Bothriocephalidae) and Khawia sinensis Hsü, 1935 (Caryophyllidea: Lytocestidae) belong to the most important species as potential pathogens of carp in aquacultures (Bauer et al. 1973, Hoole 1994, Williams \& Jones 1994).
The latter species out-competed the autochthonous caryophyllidean tapeworm Caryophyllaeus fimbriceps Annenkova-Chlopina, 1919, which had been reported to be an important parasite of carp in Central and Eastern Europe, including Russia, in the 1950s and 1960s (Bauer et al. 1973, Scholz 1989, Bauer 1991, Hoole 1994). During the last decades, C. fimbriceps has almost disappeared from the area of its original distribution (Scholz 1989).

Recently, another cestode of the order Caryophyllidea (Lytocestidae), Atractolytocestus huronensis Anthony, 1958, has been reported from Europe. The cestode was originally described from the common carp from the Huron River, Michigan, USA (Anthony 1958), and reported to be exclusively from North America until the late 1990s (Hoffman 1967, 1999, 
Jones \& Mackiewicz 1969, Amin 1986, Amin \& Minckley 1996). Considering the fact that carp is not indigenous to North America and occurred originally in eastern Asia (Baruš et al. 2002), it is probable that $A$. huronensis is also of Asian origin. In Europe, A. huronensis was first found in the common carp in England, but its occurrence was only mentioned in abstracts from national conferences (Chubb et al. 1996, Kirk et al. 2003). The most detailed account dealing with $A$. huronensis from Europe was provided by Majoros et al. (2003), who reported its frequent occurrence in cultured carp in Hungary. Molnár et al. (2003) studied the pathological effect of $A$. huronensis on its carp host.

Studies on helminth parasites of wild fish of the Tisa River in southeastern Slovakia and parasitological examinations of common carp from fishponds and water reservoirs in Slovakia and the Czech Republic have revealed the occurrence of caryophyllidean tapeworms that are indistinguishable from Atractolytocestus huronensis. In the present paper, the tapeworms found are briefly described and data on their distribution and rates of infection in carp are provided.

\section{MATERIALS AND METHODS}

In Slovakia, tapeworms were obtained from 16 common carp Cyprinus carpio carpio L. from the Tisa River near Vel'ké Trakany and 13 farmed common carp from the Slovakian-Hungarian cross-border water reservoir Vel'ký Kamenec, both southeastern Slovakia, in May, September and October 2003. A total of 29 carp (of length 227 to $460 \mathrm{~mm}$ ) were caught in 2002 and 2003 using gill nets, and by angling. In the Czech Republic, 29 cultured carp (of length 160 to $560 \mathrm{~mm}$ ) were fished from Ženich, Staré jezero and Nový Vdovec ponds near Třeboň and Bošilecký pond near Veselí nad Lužnicí, South Bohemia, in October and November 2003. The worms isolated from the anterior part of the host's intestines were washed in saline, fixed in hot $4 \%$ formaldehyde, stained with iron hydrochloric carmine, dehydrated in an ethanol series and mounted in Canada balsam as permanent preparations (Scholz \& Hanzelová 1998). Measurements are in $\mu \mathrm{m}$ except where indicated.

In addition, tapeworms from carp collected in several fishponds near Budapest, Hungary, and processed by the same method were also studied. The following vouchers of Atractolytocestus huronensis from carp in North America were used for comparison: 3 specimens from Wisconsin, USA (US National Parasite Collection, Beltsville, USA; Collection No. 78662); 3 specimens from Arizona, USA (Systematics Research Collections, University of Nebraska State Museum, Lincoln, USA; Collection No. 38728); 2 specimens from New Hamp- shire, USA 1 specimen from Knoxville, Tennessee, $\mathrm{USA}_{i} 1$ specimen from Texas, USA; and 1 specimen from Oklahoma, USA.

Specimens from Slovakia and the Czech Republic have been deposited at the Parasitological Institute, Slovak Academy of Sciences, Košice, the Institute of Parasitology, Academy of Sciences of the Czech Republic in České Budějovice, the Natural History Museum, London, UK, the US National Parasite Collection, Beltsville, USA, and Systematics Research Collections, University of Nebraska State Museum, Lincoln, USA.

\section{RESULTS}

Tapeworms found in free living and cultured common carp from Slovakia and the Czech Republic possess characteristics typical of the genus Atractolytocestus Anthony, 1958, especially the shape of the scolex (Fig. 1A-C; see Mackiewicz 1994), the presence of vitelline follicles uninterrupted along the ovarian lobes (Fig. 1A,D), cortical (Fig. 1G), separate gonopores and the presence of an opening into a shallow common genital atrium (Fig. 1E,F). The tapeworms were identified as Atractolytocestus huronensis Anthony, 1958 because they only had 14 to 20 testes beginning far posterior relative to the scolex and always posterior to the first vitelline follicles (Fig. 1A-C, Table 1). The distribution of the testes within the body was rather stable in all specimens. The first (anteriormost) testes were usually located in the median field posterior to the scolex and the last (posteriormost) 4 to 6 testes were present lateral to the cirrus-sac (Fig. 1D).

The present findings are the first records of Atractolytocestus huronensis from Slovakia and the Czech Republic.

\section{DISCUSSION}

The tapeworms recently found in Slovakia and the Czech Republic highly correspond in morphology and measurements to those of Atractolytocestus huronensis (see Anthony 1958). Species identification was confirmed by their comparison with vouchers of A. huronensis from North America (Table 1).

Two species are currently recognised as valid within the genus Atractolytocestus: A. sagittatus, synonymous with Markevitschia sagittata (Kulakovskaya \& Akhmerov 1965); and A. huronensis Anthony, 1958 (typespecies) (Jones \& Mackiewicz 1969, Mackiewicz 1994, Scholz et al. 2001).

Atractolytocestus huronensis is distinguished from A. sagittatus by a much lower number of testes as well as by testes distribution (Kulakovskaya \& Akhmerov 
1965, Protasova et al. 1990, Scholz et al. 2001, Majoros et al. 2003; Table 2). In A. sagittatus, testes are much more numerous (estimated at ca. $\geq 200$ to 300 ) and occupy a larger region of the body than in A. huronensis, extending from the posterior margin of the scolex to the anterior margin of the ovarian arms (Scholz et al. 2001).

The tapeworms from Slovakia and the Czech Republic had about 9 to 20 testes, which agrees with the number of testes found in Atractolytocestus huronensis tapeworms from North America (6 to 18 testes,
Anthony 1958, Jones \& Mackiewicz 1969, present study; Table 1). On the other hand, worms from Hungary were reported to have only 3 to 5 testes or even none in some specimens (Majoros et al. 2003). An extremely low number of testes may be related to the fact that $A$. huronensis was described to have triploid and parthenogenetic populations in North America (Jones \& Mackiewicz 1969). However, the precise number of testes was very difficult to count in A. huronensis because numerous vitelline follicles form a compact field, filling the cortex (Fig. 1F) and overlapping the testes. Therefore, the data provided by Majoros et al. (2003), especially the complete absence of testes in some specimens, should be confirmed. Indeed, a study of a few A. huronensis specimens from fishpond carp from Hungary has revealed that the actual number of testes is higher than reported by Majoros et al. (2003). Although the testes were difficult to count, 6 to 10 testes were found in 5 specimens (Table 1).

Chubb et al. (1996) synonymised Atractolytocestus sagittatus with $A$. huronensis in a presentation at a national conference but no data supporting this conclusion were provided. Based on previous studies on Atractolytocestus tapeworms (Scholz et al. 2001) and the results presented here, we provisionally consider $A$. sagittatus to be a valid taxon until its conspecificity with $A$. huronensis is confirmed, in particular by DNA analyses.

The present findings support the assumption of Majoros et al. (2003) about the probable occurrence of Atractolytocestus huronensis in central European countries other than Hungary. Further dissemination of $A$. huronensis throughout continental Europe cannot be excluded, mainly due to the fact that carp from South Bohemia are exported to many countries.

The presence of Atractolytocestus huronensis in the common carp from the Tisa River at the border of Slovakia with the Ukraine and Hungary is also significant from an epizootiological point of view. The Tisa River drains large parts of Romania, the Ukraine, Slovakia and Hungary, and enters the Danube River as a main tributary within the territory of Slovenia. The occurrence of the tapeworm in wild fish populations in this river may facilitate its rapid dispersion to other countries of central and south east Europe. Previous
Fig. 1 Atractolytocestus huronensis from common carp Cyprinus carpio carpio. (A) Total view; $(\mathrm{B}, \mathrm{C})$ anterior part of the body; (D) posterior part of the body; (E) lateral view and (F) frontal view of terminal genitalia; $(G)$ arrangement of testes and vitellaria in cross section. $\mathrm{cs}=$ cirrus sac; cga = common genital atrium; ilm = inner longitudinal musculature $; \mathrm{mg}=$ male gonopore; $\mathrm{t}=$ testes; $\mathrm{uvp}=$ utero-vaginal pore $; \mathrm{vf}=$ vitelline follicles 
Table 1. Atractolytocestus huronensis. Characteristics of the cestode from different geographical regions

\begin{tabular}{|c|c|c|c|c|c|c|c|}
\hline \multirow[t]{2}{*}{ Host } & \multicolumn{2}{|c|}{ Slovakia } & \multirow{2}{*}{$\begin{array}{l}\text { Czech Republic } \\
\text { Present data } \\
\text { Farmed carp } \\
(\mathrm{n}=16)\end{array}$} & \multicolumn{2}{|c|}{ Hungary } & \multicolumn{2}{|c|}{ USA } \\
\hline & $\begin{array}{l}\text { Present data } \\
\text { Common carp } \\
\quad(\mathrm{n}=52)\end{array}$ & $\begin{array}{l}\text { Present data } \\
\text { Farmed carp } \\
\quad(\mathrm{n}=15)\end{array}$ & & $\begin{array}{c}\text { Majoros et al. (2003) } \\
\text { Farmed carp } \\
(\mathrm{n}=5)\end{array}$ & $\begin{array}{l}\text { Present data } \\
\text { Farmed carp } \\
\qquad(\mathrm{n}=5)\end{array}$ & $\begin{array}{l}\text { Anthony }(1958)^{\mathrm{a}} \\
\text { Common carp } \\
(\mathrm{n}=10)\end{array}$ & $\begin{array}{c}\text { Present data } \\
\text { Common carp } \\
\text { (n = 11) }\end{array}$ \\
\hline Body length $(\mathrm{mm})$ & $5.5-12.0$ & $5.0-8.0$ & $4.0-9.0$ & $3.0-9.0$ & $3.0-7.5$ & $5.0-18.0$ & $4.0-8.5$ \\
\hline Body width (mm) & $0.6-1.2$ & $0.5-0.8$ & $0.5-0.9$ & $0.5-1.2$ & $0.4-0.6$ & $0.9-2.0$ & $0.6-1.5$ \\
\hline Scolex width & 484-974 & $516-741$ & 415-938 & - & $342-497$ & - & $414-900$ \\
\hline \multicolumn{4}{|c|}{ Distance between first vitelline follicles to anterior extremity $(\mathrm{mm})$} & - & $0.8-1.8$ & - & $0.8-1.6$ \\
\hline \multicolumn{8}{|c|}{ Distance between first testes to anterior extremity $(\mathrm{mm})$} \\
\hline & $1.4-2.6$ & $1.1-1.5$ & $1.0-2.6$ & - & $1.0-2.2$ & - & $1.1-2.6$ \\
\hline \multicolumn{8}{|c|}{ Distance between first vitelline follicles and first testes } \\
\hline & 135-579 & 250-384 & 213-703 & - & $156-407$ & - & 120-999 \\
\hline Testis number & $14-20$ & 16-20 & 9-14 & $0-5$ & 6-10 & $6-18$ & 12-17 \\
\hline Cirrus-sac length & $405-780$ & $506-617$ & $350-555$ & $350-450$ & $232-417$ & $256-457$ & $320-416$ \\
\hline Cirrus-sac width & $260-456$ & 299-374 & $214-347$ & & $210-276$ & - & $205-264$ \\
\hline Ovary width & $470-720$ & $421-574$ & $297-482$ & $600-900$ & $237-440$ & - & 266-885 \\
\hline Ovarian arm length & $360-1024$ & 446-703 & $365-691$ & $800-1100$ & 203-466 & $670-920$ & $167-847$ \\
\hline Ovarian arm width & $128-240$ & $134-210$ & $117-172$ & - & $83-147$ & - & 69-361 \\
\hline \multicolumn{8}{|c|}{ Extent of uterus in relation to length of testicular area } \\
\hline & $1 / 3-1 / 2$ & $1 / 3-1 / 2$ & $1 / 3-1 / 2$ & - & $1 / 4-1 / 3$ & $1 / 2$ & $1 / 3-1 / 2$ \\
\hline Egg length & $47-65$ & $48-52$ & $46-67$ & - & $47-50$ & $46-57$ & $40-52$ \\
\hline Egg width & $28-39$ & $35-36$ & $30-39$ & - & $28-31$ & $30-37$ & $26-35$ \\
\hline Prevalence (\%) & 56 & 67 & 38 & & & & \\
\hline \multicolumn{8}{|c|}{ Mean intensity of infection (range) } \\
\hline & $16.0(1-85)$ & $4.6(1-12)$ & $10.4(1-28)$ & & & & \\
\hline${ }^{\mathrm{a} O}$ Original descriptio & & & & & & & \\
\hline
\end{tabular}

Table 2. Comparison of measurements of Atractolytocestus huronensis and Atractolytocestus sagittatus. A. sagittatus after Kulakovskaya \& Akhmerov (1965), Demshin \& Dvoryadkin (1981), Protasova et al. (1990), and Scholz et al. (2001)

\begin{tabular}{|c|c|c|}
\hline & $\begin{array}{c}\text { Atractolytocestus } \\
\text { huronensis }\end{array}$ & $\begin{array}{c}\text { Atractolytocestus } \\
\text { sagittatus }\end{array}$ \\
\hline Body length (mm) & $3.0-18.0$ & $3.0-13.5$ \\
\hline Body width (mm) & $0.4-2.0$ & $0.8-2.23$ \\
\hline Scolex width & $342-974$ & $325-2380$ \\
\hline \multicolumn{3}{|c|}{ Distance between first vitelline follicles to anterior extremity (mm) } \\
\hline \multicolumn{3}{|c|}{ Distance between first testes to anterior extremity $(\mathrm{mm})$} \\
\hline \multicolumn{3}{|c|}{ Distance between first vitelline follicles and first testes } \\
\hline Testis number & $0-20$ & $75-226$ \\
\hline Cirrus-sac length & $232-780$ & $300-810$ \\
\hline Cirrus-sac width & $205-456$ & $300-690$ \\
\hline Ovary width & $237-900$ & $960-1580$ \\
\hline Ovarian arm length & $167-1100$ & $150-1120$ \\
\hline Ovarian arm width & $69-361$ & $150-390$ \\
\hline \multicolumn{3}{|c|}{ Extent of uterus in relation to length of testicular area } \\
\hline Egg length & $40-67$ & $40-58$ \\
\hline Egg width & $26-39$ & $22-37$ \\
\hline
\end{tabular}

surveys on fish parasites in the Tisa River basin carried out in the 1970s did not reveal the presence of this cestode (Žitňan 1966, Ergens et al. 1975, Moravec 2001). It is evident that $A$. huronensis has been introduced into this region recently, as assumed by Majoros et al. (2003) and Molnár et al. (2003).

In the same region (the Latorica River, Tisa River basin, southeastern Slovakia), another helminth parasite non-indigenous in Europe has recently appeared. Košuthová et al. (2004) reported the presence of the cestode Nippotaenia mogurndae Yamaguti \& Miyata, 1940 (Nippotaeniidea), a specific parasite of the Chinese sleeper Perccottus glenii (Perciformes: Odontobutidae). This fish has been artificially introduced from northeastern Korea and the Amur River basin to European Russia, the Ukraine, Hungary, Poland and Slovakia (Koščo et al. 2003, Reshetnikov 2003). The distribution area of $N$. mogurndae was originally restricted to Japan and the Far East, but it has been introduced to Europe together with its host, which was first reported from Slovakia in 1998 (Kautman 1999). 
Acknowledgements. Thanks are due to Dr. S. L. Gardner, University of Nebraska State Museum, Lincoln, USA, and Dr. P. Pillit, US National Parasite Collection, Beltsville, Maryland, USA, for the loan of museum specimens; Dr. O. M. Amin, Parasitology Center, Tempe, USA, for providing relevant literature; Prof J. S. Mackiewicz, University of New York, Albany, USA, for providing specimens; and Dr. Cs. Székely and Prof. K. Molnár, Veterinary Medical Research Institute, Budapest, Hungary, for collecting Atractolytocestus huronensis tapeworms from Hungary. The authors acknowledge the technical assistance of L'. Burik from the Parasitological Institute SAS Košice, Slovakia, and M. Borovková and R. Kuchta, Institute of Parasitology, AS CR, České Budějovice, Czech Republic. This study was supported by the Scientific Grant Agency of Slovakia (VEGA, Project No. 2/4177/04 to V.H.), the Grant Agency of the Czech Republic (Project No. 524/04/0342 to T.S.) and the research project of the Institute of Parasitology, AS CR, České Budějovice (Project No. Z6 022 909).

\section{LITERATURE CITED}

Amin OM (1986) Caryophyllaeidae (Cestoda) from lake fishes in Wisconsin with a description of Isoglaridacris multivitellaria sp. n. from Erimyzon sucetta (Catostomidae). Proc Helminthol Soc Wash 53:48-58

Amin OM, Minckley WL (1996) Parasites of some fish introduced into an Arizona reservoir, with notes on introductions. J Helminthol Soc Wash 63:193-200

Anthony JD (1958) Atractolytocestus huronensis n. gen., n. sp. (Cestoda: Lytocestidae) with notes on its morphology. Trans Am Microsc Soc 77:383-390

Baruš V, Peňáz M, Kohlmann K (2002) Cyprinus carpio (Linnaeus, 1758) In: Bănărescu PM, Paepke HJ (eds) The freshwater fishes of Europe. Aula-Verlag, Wiebelsheim, p 86-179

Bauer ON (1991) Spread of parasites and diseases of aquatic organisms by acclimatization: a short review. J Fish Biol 39:679-686

Bauer ON, Musselius VA, Strelkov YA (1973) Diseases of pond fishes. Israel Programme for Scientific Translations, Jerusalem (in Russian)

Chubb JC, Kirk R, Wellby I (1996) Caryophyllaeid tapeworm Atractolytocestus huronensis Anthony, 1958 (= Markevitschia sagittata Kulakovskaya et Akhmerov, 1965) in carp Cyprinus carpio L. in British Isles-another translocation? In: Abstracts of the Spring Meeting of the British Society of Parasitology, University of Wales, Bangor, p 66

Demshin NI, Dvoryadkin VA (1981) The development of Markevitschia sagittata (Cestoidea: Caryophyllidae), a parasite of the Amur wild carp, in the external conditions and intermediate host. Parazitologiya 15:113-117 (in Russian)

Ergens R, Gussev VA, Izyumova NA, Molnár K (1975) Parasite fauna of fishes of the Tisa River basin. Academia, Prague

Hoffman GL (1967) Parasites of North American freshwater fishes. University of California Press, Berkeley, CA

Hoffman GL (1999) Parasites of North American freshwater fishes, 2nd edn. Comstock Publishing Associates, Ithaca, NY

Hoole D (1994) Tapeworm infection in fish: past and future problems. In: Pike AW, Lewis JW (eds) Parasitic diseases of fish. Samara Publishing Limited, Tresaith, p 119-140

Editorial responsibility: Wolfgang Körting,

Hannover, Germany
Jones AW, Mackiewicz JS (1969) Naturally occurring triploidy and parthenogenesis in Atractolytocestus huronensis Anthony (Cestoidea: Caryophyllidea) from Cyprinus carpio L. in North America. J Parasitol 55:1105-1118

Kautman J (1999) Perccottus glenii Dybowski, 1877 from East Slovakian water bodies. Protected areas of Slovakia, SAE Banská Bystrica 40:20-22 (in Slovakian)

Kennedy CR (1994) The ecology of introductions. In: Pike AW, Lewis JW (eds) Parasitic diseases of fish. Samara Publishing Limited, Tresaith, p 189-209

Kirk RS, Veltkamp CJ, Chubb JC (2003) Identification of Atractolytocetus huronensis (Caryophyllidea: Lytocestidae) from carp (Cyprinus carpio) using histological and ashing techniques. In: Abstracts of the Spring Meeting of the British Society of Parasitology, Manchester, p 45-46

Koščo J, Lusk S, Halačka K, Lusková W (2003) The expansion and occurrence of Amur sleeper (Perccottus glenii) in eastern Slovakia. Folia Zool 52:329-336

Košuthová L, Letková V, Koščo J, Košuth P (2004) First record of Nippotaenia mogurndae Yamaguti and Miyata, 1940 (Cestoda: Nippotaeniidea), a parasite of Perccottus glenii Dybowski, 1877, from Europe. Helminthologia 41:54-56

Kulakovskaya OP, Akhmerov AC (1965) Markevitschia sagittata n. gen. n. sp. (Cestoda, Lytocestidae) from common carp in the Amur River. Parasites and parasitoses of man and animals. Naukova Dumka, Kiev, p 264-271 (in Russian)

Mackiewicz JS (1994) Order Caryophyllidea van Beneden in Carus, 1863. In: Khalil LF, Jones A, Bray RA (eds) Keys to the cestode parasites of vertebrates. $C A B$ International Wallingford, Oxon, p 21-43

Majoros G, Csaba G, Molnár K (2003) Occurrence of Atractolytocestus huronensis Anthony, 1958 (Cestoda: Caryophyllaeidae), in Hungarian pond-farmed common carp. Bull Eur Assoc Fish Pathol 23:167-175

Molnár K, Majoros G, Csaba G, Székely C (2003) Pathology of Atractolytocestus huronensis Anthony, 1958 (Cestoda, Caryophyllaeidae) in Hungarian pond-farmed common carp. Acta Parasitol 48:222-228

Moravec F (2001) Checklist of the metazoan parasites of fishes of the Czech Republic and Slovak Republic (1873-2000). Academia, Prague

Protasova EP, Kuperman BI, Roitman VA, Poddubnaya LG (1990) Caryophyllid tapeworms of the fauna of the USSR. Nauka, Moscow (in Russian)

Reshetnikov AN (2003) The introduced fish, rotan (Perccottus glenii), depresses populations of aquatic animals (microinvertebrates, amphibians, and fish). Hydrobiologia 510: $83-90$

Scholz T (1989) Amphilinida and Cestoda, parasites of fish in Czechoslovakia. Acta Sci Nat Brno 23:1-56

Scholz T, Hanzelová V (1998) Tapeworms of the genus Proteocephalus Weinland, 1858 (Cestoda: Proteocephalidae), parasites of fishes in Europe. Studie AV ČR, Academia, Prague

Scholz T, Shimazu T, Olson PD, Nagasawa K (2001) Caryophyllidean tapeworms (Platyhelminthes: Eucestoda) from freshwater fishes in Japan. Folia Parasitol 48: $275-288$

Williams HH, Jones A (1994) Parasitic worms of fish. Taylor \& Francis, London

Žitňan R (1966) Cestoidea and Trematoidea of fishes from the flowing waters of the Tisa River lowlands (ČSSR) II. Biologia 21:763-770 (in Slovakian)

Submitted: April 21, 2004; Accepted: June 28, 2004

Proofs received from author(s): October 13, 2004 